\title{
Logistics Strategies And Practices \\ IN VENEZUELA
}

\section{Ángel Díaz Matalobos}

$$
\begin{gathered}
\text { Instituto de Empresa } \\
\text { Dept. Operations } \\
\text { \& Technology Management } \\
\text { C/ María de Molina, 12, 5 } \\
\text { 28006, Madrid - Spain } \\
\text { angel.diaz@ie.edu }
\end{gathered}
$$

\section{Cándido Pérez Costela}

Instituto de Estudios Superiores

de Administración (I.E.S.A)

Av. IESA. San Bernardino

Caracas 1010 Venezuela

candido.perez@iesa.edu.ve

\begin{abstract}
This paper presents an empirical and statistical analysis identifies the key characteristics and opportunities of logistics in Venezuela. Among the key findings are conservative approaches to logistics in a protected market whose environment is changing faster than preferred by the responsible actors, limiting the application of modern logistics practices. This and other considerations, such as geographical location, production of commodities and the identification in the strategy of the firms of the need for better logistics practices indicate important opportunities for the application of modern logistics practices.
\end{abstract}

\section{Keywords}

Logistics in Venezuela, conservative approaches, modern logistics practices 


\section{Introduction}

Logistics management has become a strategic tool in the success of business plans, due to its impact on cash flow generation and service quality. The processes of transformation and delivery demand a strategic vision of the links among manufacturing, purchasing and marketing, including organizational and environmental considerations.

Venezuela, with a promising geographical location, but with operational inefficiencies (e.g., high inventory costs -Esqueda, Díaz and Sánchez, 1996) and other market and state inefficiencies is particularly sensitive to advances in logistics. This situation is examined in this paper.

\section{Logistics in Venezuela}

Venezuela, an important emerging market (Bowman, 1998) constitutes a test bed for advanced logistic practices, due to extensive commodities production, its geographical location and a relatively low level of logistics performance.

Commodities produced in the country include petroleum and derivatives, natural gas, steel, aluminum and electricity. These are lead by Petróleos de Venezuela (PDVSA) -an state owned firm responsible for the petroleum and natural gas exploration, production and delivery- which is developing outsourcing as a focus strategy, ceding non-core activities to specialized firms.

The geographical location of Venezuela -near the continent's center of gravity, Figure 1- constitutes a comparative advantage, as the country could become a commerce hub between the north and south of the Americas. This could be facilitated by strong improvements in the efficiency of the main port of the country, Puerto Cabello (Diaz and Dresner, 1997; Gooley, 1998), and by the consolidation of the road to Manaos, Brazil (Acosta and Canakis, 1996). Other regional hubs are under development. Such are the cases of Panama, where a Pacific-Atlantic rail link will move 500,000 TEU by 2003 (Wilner, 2000) and Mexico where a similar link is also being built (Logistic Management and Distribution Report, 2001).

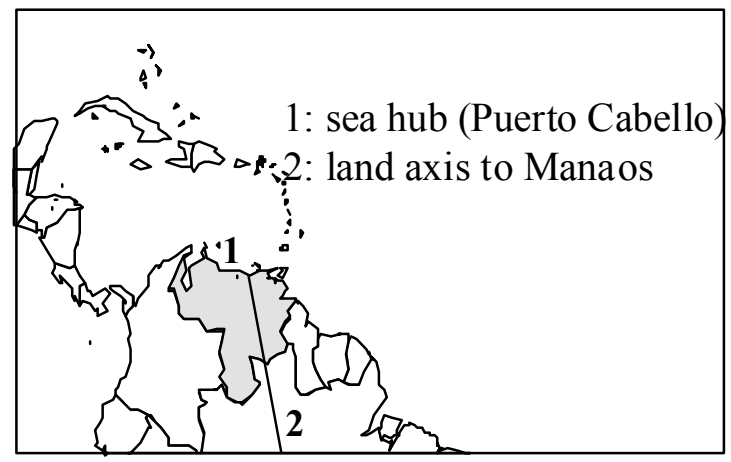

\section{Figure 1. Logistic potential of Venezuela}

These comparative advantages are marred by the backward state of competitiveness in the country. Venezuela has been ranked next-to-last in the world competitiveness report (IMD, 2000) for the last seven years, and this could be partially related to very small production scales and inefficient distribution channels (Esqueda et. al., 1996).

Logistics techniques and practices such as cross-docking, outsourcing in transportation and warehousing, process orientation (driven by ERP implementations), and considerable investments in information technology could help to improve this situation, even when other advanced practices like 
benchmarking, network design and cooperative schemes are still lacking. This profile is similar to the one described for Latin America as a whole by Zinn (1996).

With this motivation a survey of key logistics players in Venezuela was conducted, resulting in a map of current practices, strategies and logistics opportunities

\section{The Logistic Survey}

The instrument was designed in mid-1998 as part of an academic collaboration between a consulting firm (AT Kearney) and a business school (IESA). This was the first logistic poll documented in Venezuela.

The respondents fulfilled Likert-type scales and numerical questions. The questions were designed to obtain descriptive information on logistic practices, while avoiding the disclosure of sensible financial information.

The sample and profile of the firms

A total of 384 logistics providers and users were initially contacted, with 31 responses received by February 1999. The low proportion of responses ( 8 per cent) is about average for Venezuela, where many companies do not have formal information services, or are suspicious of disclosing information.

Respondents are representative of the industrial and service sectors, employ 820 persons in average with annual sales close to US \$ 35 million, and exports of about $15 \%$ of total sales. They tend to have large organizational structures for their sizes, averaging six hierarchical levels.

This article continues the exploratory study previously performed by Díaz and Pérez (2000). The raw data obtained was processed with standard statistical methods (including correlation and factor analysis), to study the relationship patterns among the variables in the survey ${ }^{1}$.

\section{Logistics Strategy}

Among key results it was found that logistics strategy is mainly concerned with the integration of the supply chain: Long-term relationships with customers and suppliers, on-site services and delivery dependability, as shown in Figure 1. This is in line with the Mega-trends reported by Bowersox, Closs and Stank (2000).

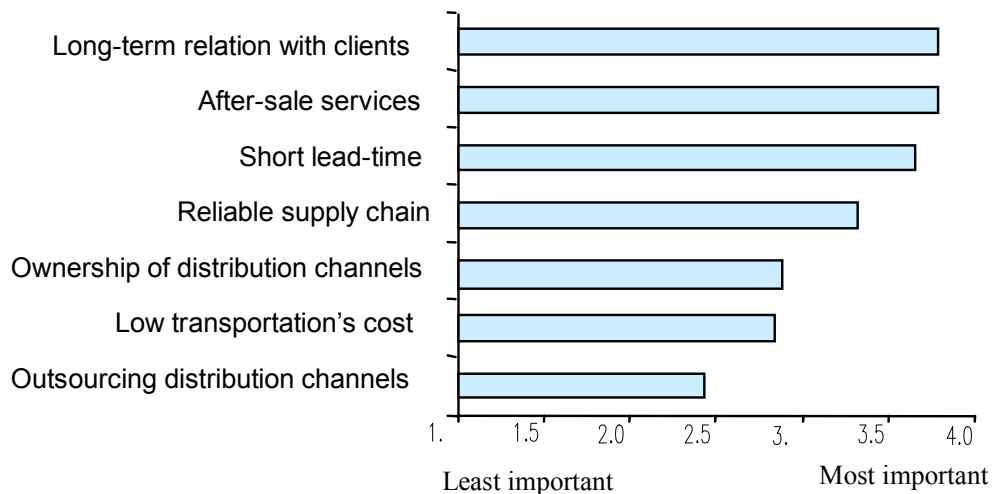

Figure 1. Key strategic considerations in Venezuelan’ logistics

\footnotetext{
${ }^{1}$ Details of the survey in Díaz and Pérez (2000)
} 
Response speed was described as more valuable than transportation costs, suggesting that efficacy is preferred to efficiency, a usual trend in protected markets.

The development of proprietary distribution channels is thought of as safer than outsourcing -implying the absence of reliable third-party providers.

The main perceived threats to logistics in Venezuela are economic uncertainty (due to short-term economic policies), infrastructure limitations and human resources scarcity.

Suppliers' selection policies reveal the behavior of Venezuelan managers: quality, price and dependability were reported as the key influential characteristics. This looks again as a consequence of the use of hierarchies -instead of markets- and conglomerates (subcontracting with firms owned by the same economic group).

Key factors in the logistic strategy

The respondents' opinions about key elements in logistics were processed using factor analysis. Table 1 shows the association among low transportation costs (COSTS), reliable providers network (NET) and ownership of the distribution channel: outsourcing is viewed as positive (3PCHANN) and total ownership as negative (OWNCHANN). This factor could be named "Costs view".

Another interesting relationship showed is among after sales services (AFTSALES), reliable network suppliers and long-term relationship with clients (CLIENTS). This shows long-term downstream commitments.

\begin{tabular}{lccc}
\multicolumn{4}{c}{ Rotated Component Matrix $^{a}$} \\
\hline \multicolumn{3}{c}{ Component } \\
& 1 & 2 & 3 \\
\hline 3PCHANN & .876 & \\
OWNCHANN & -.853 & .448 \\
COSTS & .569 & .933 \\
DELIVERY & & .538 \\
AFTSALES & & .727 & \\
NET & .500 & .400 & \\
CLIENTS & & .900 & \\
\hline Extraction Method: Principal Component Analysis. & \\
a. Rotation Method: Varimax with Kaiser normalization (converged in 4 ite rations)
\end{tabular}

\section{Table 1. Factor Analysis results for key elements in logistics (Rotated Component Matrix)}

The association among low transportation costs, short lead-times (DELIVERY) and after sales services suggest a commitment to customer satisfaction. Most of the variance is collected by the three factors described above, as shown in appendix 2 (table A1, explained variance of key logistic strategy factors).

A clearly marked relationship between long-term relationship with clients and after sales service was expected. This is empirically proved in Table 2 where results of a linear regression became significant at standard confidence levels.

\begin{tabular}{|c|c|c|c|c|c|c|}
\hline \multirow[b]{2}{*}{ Model } & & \multicolumn{2}{|c|}{$\begin{array}{l}\text { Unstandardized } \\
\text { Coefficients }\end{array}$} & \multirow{2}{*}{$\begin{array}{c}\text { Standardized } \\
\text { Coefficients } \\
\text { Beta }\end{array}$} & \multirow[b]{2}{*}{$t$} & \multirow[b]{2}{*}{ Sig } \\
\hline & & $\mathrm{B}$ & Std. Error & & & \\
\hline 1 & $\begin{array}{l}\text { (Constant) } \\
\text { AFTSALES }\end{array}$ & $\begin{array}{r}2.937 \\
.253\end{array}$ & $\begin{array}{l}.342 \\
.098 \\
\end{array}$ & .445 & $\begin{array}{l}8.585 \\
2.580\end{array}$ & $\begin{array}{l}.000 \\
.016\end{array}$ \\
\hline
\end{tabular}

Table 2. Linear Regression between CLIENTS and AFTSALES 
Threats to logistics development in Venezuela

Conducting a similar analysis, the perceptions of actual and future threats to the development of logistic practices in Venezuela were obtained. The resulting factors can be described as external and internal.

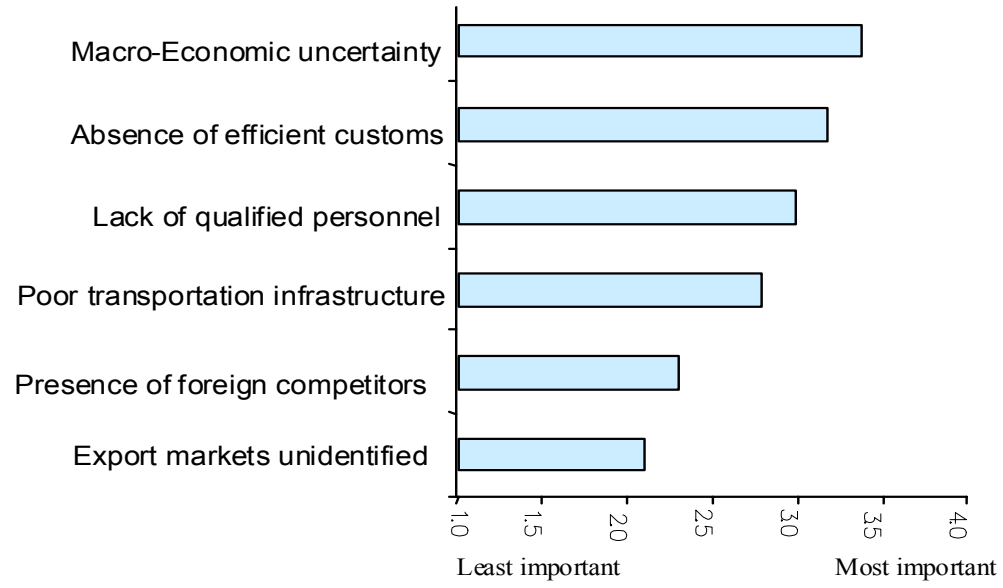

Figure 2. Threats to the development of logistics in Venezuela

Factor analysis results are included in Table 3. The respondents related the lack of transport infrastructure (INFRAEST), foreign competition (COMPETIT), and difficulties identifying foreign markets to export (UNKNOWN). This factor was called external environment, as firms have little control on it.

The other relevant factor includes macro-economic uncertainty (ENVIRON), lack of adequate custom services (SERVICE), and absence of qualified personnel (PERSON). This factor was called internal, or national, environment.

\begin{tabular}{lcc}
\multicolumn{3}{c}{ Rotated Component Matrix a } \\
\hline & \multicolumn{2}{c}{ Component } \\
& 1 & 2 \\
\hline ENVIRON & .819 & -.258 \\
COMPETIT & -.274 & .691 \\
INFRAST & .249 & .682 \\
SERVICE & .722 & .271 \\
UNKNOWN & .478 & .598 \\
PERSON & .630 & \\
\hline
\end{tabular}

Extraction Method: Principal Component Analysis

Rotation Method: Varimax with Kaiser Normal ization

a. Rotation converged in 3 iterations

Table 3 Factor Analysis for threats to logistics development

The total explained variance, showed in appendix 2 (Table A2) is approximately 57\% suggesting some limitations in the explanatory power of the factor analysis. Successive tests were done but each new factor only contains one variable. 
The relations obtained in internal environment suggested additional studies, as the variable qualified personnel does not contain an identifiable pattern. This lead to calculate the correlation between those variables, presented in Table 6 .

\begin{tabular}{lcccc}
\multicolumn{5}{c}{ Correlations } \\
\hline & ENVIRON & SERVICE & PERSON \\
\hline Pearson & ENVIRON & 1.000 & $.379^{*}$ & $.452^{*}$ \\
Correlation & SERVICE & $.379^{*}$ & 1.000 & .094 \\
& PERSON & $.452^{*}$ & .094 & 1.000 \\
\hline
\end{tabular}

$\left.{ }^{*}\right)$ Correlation is significant at the 0:05 level (2-tailed).

\section{Table 4. Correlation between variables (internal environment factors)}

There appears to be a significant correlation between ENVIRON and each of the other two variables, but no relation between SERVICE and PERSON. It looks like a case of structural dependency linking the latter pair with macro-economic uncertainty. Structural equation models could help to confirm this hypothesis.

Criteria to select suppliers

The most important criteria to select suppliers -from the highest to the lowest degree of importance- are: quality, delivery reliability, price, response flexibility, and geographic location, Figure 3.

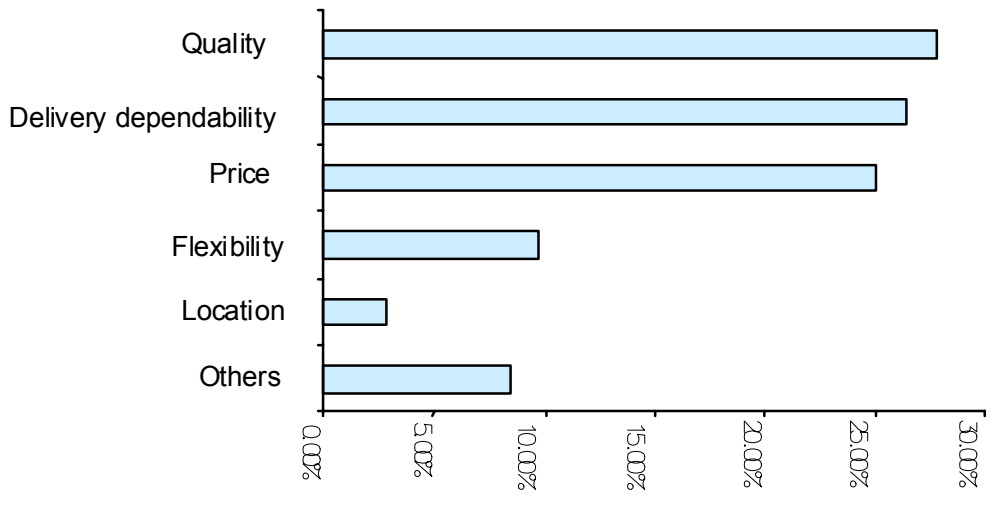

\section{Figure 3. Importance of criteria to select suppliers}

Due to the slight differences among the first three a correlation study was conducted (Table 5). The high values of correlation and significance explain the absence of dominant criteria, which explains the difficulties suffered by Venezuelan firms trying to establish strategic ventures for long-term supply chain partnerships.

\begin{tabular}{llccccc}
\hline \multicolumn{7}{c}{ Correlations } \\
\hline Pearson & FIRSTCRI & FIRSTCRI & SECONCRI & THIRDCRI & FOURTCR & FIETHCRI \\
Correlation & 1.000 & $.822^{* *}$ & $.645^{* *}$ & .339 & .484 \\
& SECONCRI & $.822^{* *}$ & $1.000^{* *}$ & $.819^{* *}$ & $.748^{*}$ & .873 \\
& THIRDCRI & $.645^{* *}$ & $.819^{* *}$ & 1.000 & $.742^{*}$ & $.981^{* *}$ \\
& FOURTCRI & .339 & $.748^{*}$ & $.742^{*}$ & 1.000 & $.981^{* *}$ \\
& FIFTHCRI & .484 & $.873^{* *}$ & $.981^{* *}$ & $.981^{* *}$ & 1.000 \\
\hline
\end{tabular}

$\left(^{* *}\right)$ Correlation is significant at the 0.01 level (2-tailed), and $\left(^{*}\right)$ at the 0.05 level (2-tailed)..

Table 5. Correlation among criteria for choosing suppliers 
Determination of customers' logistics needs

Method used to understand customers' needs were ranked. The four main methods are classic marketing tools: market research, customer surveys, analysis of services provided by competitors and focus groups with clients.

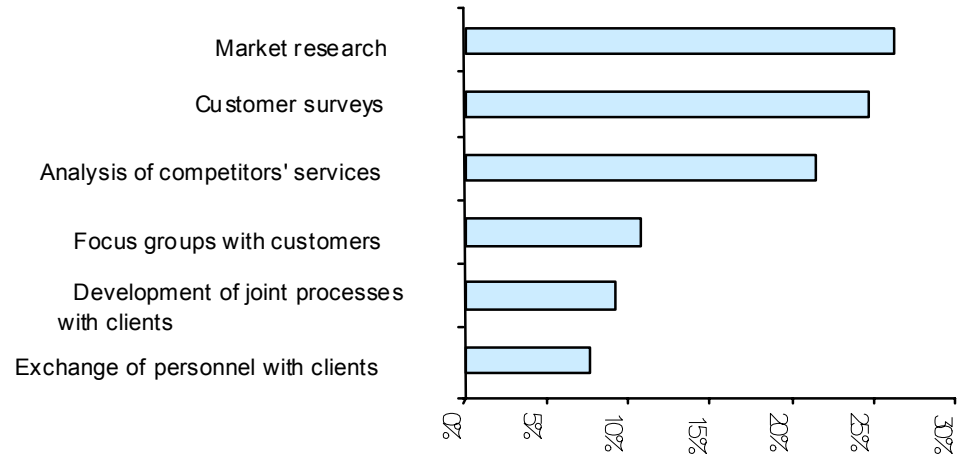

Figure 4. Methods used to determine customers' logistics needs

Again, Venezuelan companies do not perceive long-term commitment as an important strategy. Table 6 shows strong correlation among the first three techniques.

\begin{tabular}{lccccc}
\hline \multicolumn{5}{c}{ Correlations } \\
\hline Pearson & NEED1 & 1.000 & $.770^{* *}$ & $.434 *$ & .311 \\
Correlation & NEED2 & $.770^{* *}$ & 1.000 & .483 & .311 \\
& NEED3 & .434 & $.483^{*}$ & 1.000 & .311 \\
& NEED4 & .311 & .311 & .311 & 1.000 \\
\hline
\end{tabular}

Table 6. Correlation among logistic requirements

\section{Logistic Practices And Techniques}

Respondents' firms value more integration with suppliers and customers (coincident with the confessed strategy), performance evaluation and benchmarking than more recent practices like ECR. But the use of these practices is in contradiction with the perceived importance (Figure 5), and so a correlation test was performed as presented in Table 9.

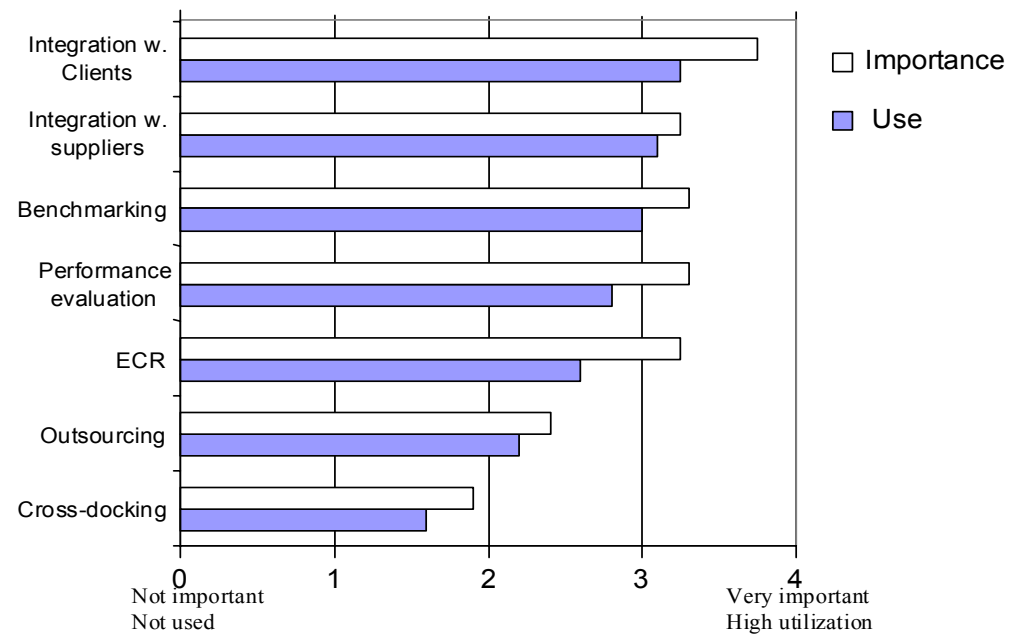




\section{Figure 5. Perceived importance and utilization of key logistics practices and techniques}

These results show the low perceived importance -prefixed IMP- of recent practices like ECR and their relation with their usage - prefixed USE.

Attention is caught by the importance assigned to integration along the supply chain (IMPSUPPL and IMPCLIEN) compared to its actual application -specially with suppliers-, and the relationship among performance (PERFO), outsourcing (OUTSO) and integration with customers (CLIEN). Logistics integration is desired, rather than implemented, according to these results.

\begin{tabular}{|c|c|c|c|c|c|c|c|c|}
\hline \multicolumn{9}{|c|}{ Correlations } \\
\hline & & IMPSUPPL & IMPCLIEN & IMPECR & IMPCROSS & IMPOUTSO & IMPERFO & IMPBENCH \\
\hline \multirow{14}{*}{$\begin{array}{l}\text { Pearson } \\
\text { Correlation }\end{array}$} & IMPSUPPL & 1.000 & $.481^{* *}$ & -.256 & -.409 & -.338 & -.021 & -.080 \\
\hline & IMPCL IEN & .481 ** & 1.000 & .163 & -.283 & -.404 * & .438 * & .133 \\
\hline & IMPECR & -.256 & .163 & 1.000 & .349 & .073 & .423 * & .191 \\
\hline & IMPCROSS & -.409 & -.283 & .349 & 1.000 & .067 & .030 & .189 \\
\hline & IMPOUTSO & -.338 & $-.404^{*}$ & .073 & .067 & 1.000 & -.236 & -.064 \\
\hline & IMPPERFO & -.021 & $.438^{*}$ & $.423 *$ & .030 & -.236 & 1.000 & $.479 * *$ \\
\hline & IMPBENCH & -.080 & .133 & .191 & .189 & -.064 & $.479 * *$ & 1.000 \\
\hline & USESUPPL & .306 & .184 & -.095 & -.291 & -.252 & .216 & .270 \\
\hline & USECLIEN & .272 & $.595^{* *}$ & -.237 & -.061 & -.116 & .392 * & .103 \\
\hline & USEECR & -.087 & -.082 & .247 & -.094 & -.031 & .169 & -.334 \\
\hline & USECROSS & .047 & .162 & .296 & .575 & -.285 & .169 & .267 \\
\hline & USEOUTSO & -.229 & -.195 & -.186 & .000 & $.485^{* *}$ & -.017 & .071 \\
\hline & USEEVALU & -.117 & -.125 & .000 & -.262 & -.202 & .632 ** & -.002 \\
\hline & USEBENCH & 171 & 175 & & & & & \\
\hline
\end{tabular}

$\left(^{* \star}\right)$ Correlation is significant at the 0.01 level (2-tailed) and $\left(^{*}\right)$ at the 0.05 level (2-tailed)

\section{Table 7. Correlation among logistic elements}

A factor analysis was performed to further study existing relations. Table 8 shows results for factors and Table a3 (appendix 2) the total variance explained.

\begin{tabular}{|c|c|c|c|c|c|}
\hline \multicolumn{6}{|c|}{ Rotated Component Matrix ${ }^{a}$} \\
\hline & \multicolumn{5}{|c|}{ Component } \\
\hline & 1 & 2 & 3 & 4 & 5 \\
\hline IMPSUPPLI & -.451 & -.342 & -.456 & .628 & .212 \\
\hline IMPCL IEN & & -.519 & -.273 & .594 & .481 \\
\hline IMPECR & .926 & & & & \\
\hline IMPCROSS & .674 & & & -.355 & .585 \\
\hline IMPOUTSO & & & .287 & -.913 & \\
\hline IMPPERFO & .347 & .899 & & & \\
\hline IMPBENCH & .884 & .253 & & & \\
\hline USESUPPL & & .505 & -.760 & .274 & \\
\hline USECLIEN & -.285 & & -.436 & & .755 \\
\hline USEECR & & & .937 & & \\
\hline USECROSS & .285 & .299 & & .208 & .863 \\
\hline USEOUTSO & -.324 & .315 & .716 & -.513 & \\
\hline USEPERFO & -.255 & .939 & & & \\
\hline USEBENCH & & & & .568 & -.215 \\
\hline
\end{tabular}

\section{Table 8. Factor Analysis of logistic practices and techniques}

The firms link outsourcing with more recent techniques (ECR, cross-docking), from the point of view of importance. This implies a particular cultural perception: outsourcing is a novelty in an environment that favors vertical integration. 
Performance is linked with evaluations (EVALU), indicating an adequate correspondence between firm's policies and practices. ECR is related directly to outsourcing, but in the opposite direction to the usage of integration with suppliers. This constitutes a logistic opportunity.

The use of benchmarking appears related to the variables just mentioned, as a tendency to perform better than competitors.

Cross-docking is linked to integration in the direction of the supplier, reflecting exigencies from the latter, more than initiatives from the supplier.

The importance of developing a network with suppliers and customers contrasts with the (opposite) relation assigned to outsourcing. The perception of the outsourcer as an intruder to the network is significant and suggests cultural misalignments. This topic is further explored in the next section.

Outsourcing

Only outsourcing of transportation is both perceived as important and widely used (Figure 6). Other activities show important gaps between perceived importance and use, denoting the implicit conflict between control and efficiency.

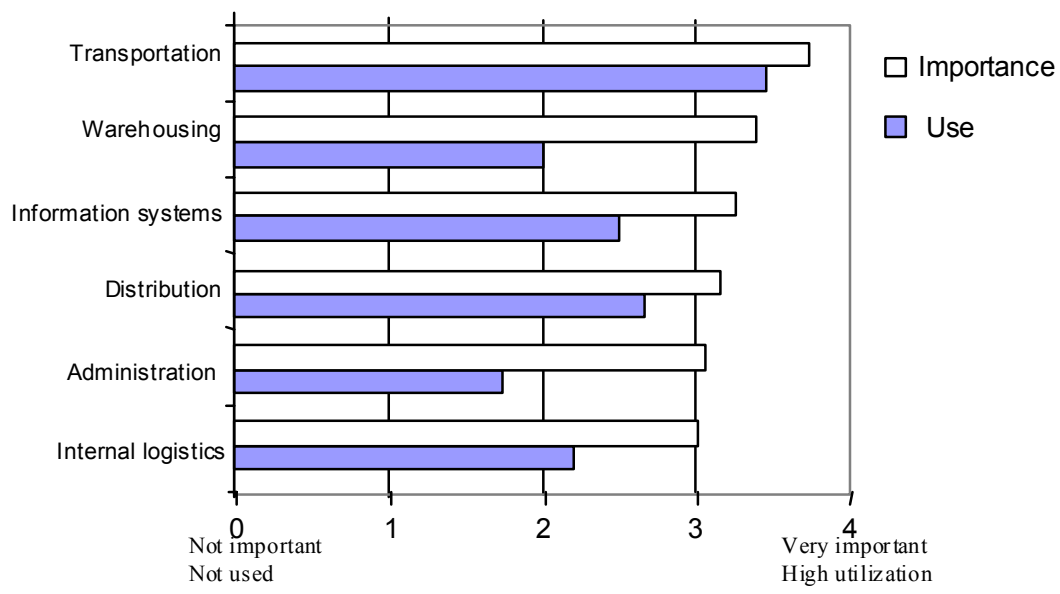

\section{Figure 6. Perceived importance and utilization of outsourcing}

The ranked reasons to outsource were focus on core competencies, improvement in service quality, better use of resources and cost reduction. The relative perception of reasons to outsource points out to a tight relation between cost reduction and efficient use of resources, besides the association with service quality improvement. This suggests an implicit direct relation between quality and cost, which may be caused by cultural factors. Table 9, a correlation study, shows the relation among these variables

Correlations

\begin{tabular}{llcccc}
\hline & & REACORE & REAQUAL & REARESOU & REACOST \\
\hline Pearson & REACORE & 1.000 & $.544^{*}$ & $.667^{* *}$ & .210 \\
Correlation & REAQUAL & $.544^{*}$ & 1.000 & $.584^{* *}$ & .347 \\
& REARESOU & $.667^{* *}$ & $.584^{\star *}$ & 1.000 & $.422^{*}$ \\
& REACOST & .210 & .347 & $.422^{*}$ & 1.000 \\
\hline
\end{tabular}

Correlation is significant at the 0.01 level (2-tailed) and $\left(^{*}\right)$ at the 0.05 level (2-tailed).

\section{Table 9. Correlation among reasons to outsource}

Therefore the quality of the provided service and efficiency are perceived as the firms' core objectives, and not cost reduction. This view could be caused by the relatively small size of the market in Venezuela.

When asked to report why not to outsource, the responses show a particular pattern: every variable analyzed (non-available services, costlier, confidentiality, and control and legal restrictions) becomes 
independent. This is shown as a correlation analysis in Table 10, which shows quite differentiated perceptions about each one of the surveyed variables.

Correlations

\begin{tabular}{|c|c|c|c|c|c|c|}
\hline \multirow{3}{*}{$\begin{array}{l}\text { Pearson } \\
\text { Correlation }\end{array}$} & & \multicolumn{3}{|c|}{ NOUTCONT NOUTUNAV NOUTCOST } & NOUTPROT & NOUTLEGA \\
\hline & NOUTCONT & $\quad 1.000$ & -.283 & -.105 & & \\
\hline & NOUTUNAV & -.283 & 1.000 & .161 & 121 & -.311 \\
\hline & NOUTCOST & -.105 & .161 & 1.000 & .097 & .093 \\
\hline & NOUTPROT & .108 & .121 & .097 & 1.000 & .023 \\
\hline & NOUTLEGA & .217 & -.311 & .093 & .023 & 1.000 \\
\hline
\end{tabular}

Table 10. Correlation among reasons to avoid outsourcing

\section{Information Technology}

To study relations between technology availability (AVA prefix) and its use- (USE prefix) seven types of technological resources were proposed to the surveyed managers: integrated systems, bar coding, tracking facilities, GIS, GPS, EDI, and Internet/Web (same order of appearance in the respective table). The reported usage was concentrated in integrated systems and bar coding technology. More than $60 \%$ of the respondents reported the other resources as unknown or not used in their firm (shown in the right axis of Figure 7 as \% of companies reporting availability of IT).

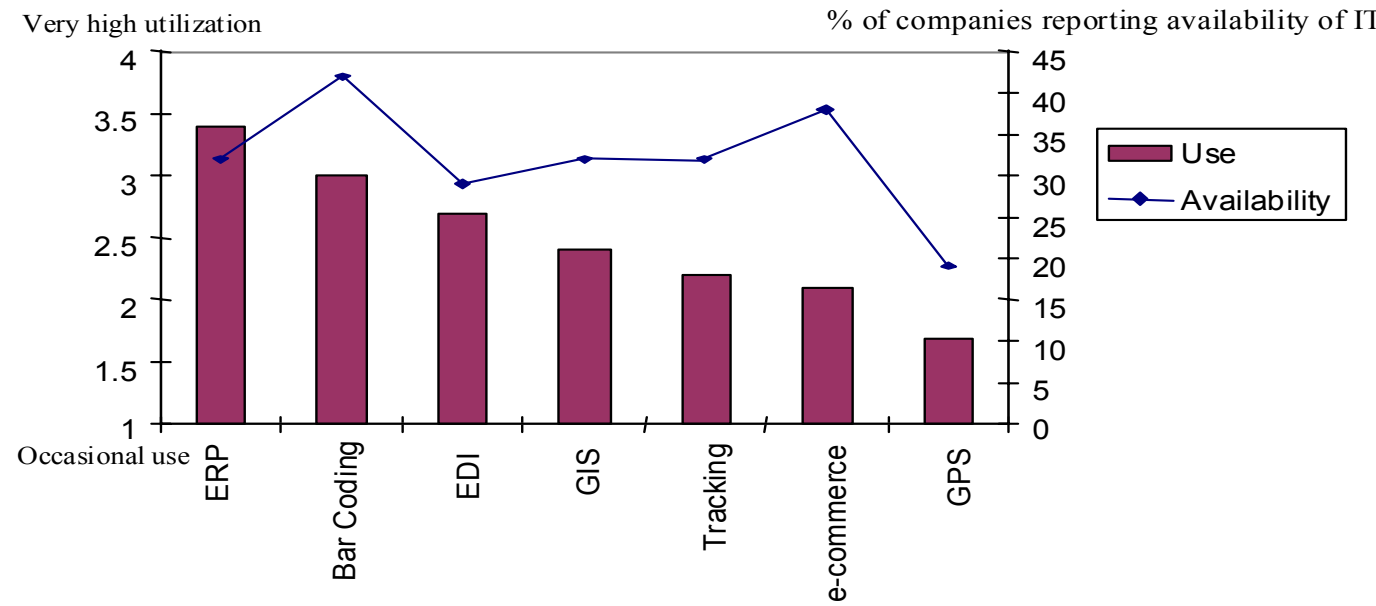

\section{Figure 7. Availability and use of logistics-related IT}

Table 11 introduces the results of a correlation study among these variables.

\begin{tabular}{|c|c|c|c|c|c|c|c|c|}
\hline \multicolumn{9}{|c|}{ Correlations } \\
\hline & & AVAERP & AVABAR & AVATRACK & AVAGIS & AVAGPS & AVAEDI & AVAWEB \\
\hline \multirow{14}{*}{$\begin{array}{l}\text { Pearson } \\
\text { Correlation }\end{array}$} & AVAERP & 1.000 & $.827^{* *}$ & .510 & .510 & $.498^{*}$ & $.681^{*}$ & .302 \\
\hline & AVABAR & $.827^{* *}$ & 1.000 & .177 & -.229 & -.234 & $.735^{*}$ & -.081 \\
\hline & AVATRACK & .510 & .177 & 1.000 & $1.000^{* *}$ & $.575^{*}$ & $.586^{*}$ & $.664^{*}$ \\
\hline & AVAGIS & .510 & -.229 & $1.000^{* *}$ & 1.000 & $.866^{* *}$ & .559 & $.704^{*}$ \\
\hline & AVAGPS & $.498^{*}$ & -.234 & $.575^{*}$ & $.866^{* *}$ & 1.000 & .501 & $.592^{*}$ \\
\hline & AVAEDI & $.681^{*}$ & $.735^{*}$ & $.586 *$ & .559 & .501 & 1.000 & $.630^{*}$ \\
\hline & AVAWEB & .302 & -.081 & .664 * & $.704^{*}$ & $.592^{*}$ & .630 * & 1.000 \\
\hline & USEERP & & & & & & .000 & $-1.000^{* *}$ \\
\hline & USEBAR & a & a & -.701 & .091 & .000 & -.686 & -.686 \\
\hline & USETRACK & .500 & -.756 & -1.000 ** & $1.000^{* *}$ & a & . a & -.866 \\
\hline & USEGIS & $1.000^{* *}$ & $.962^{*}$ & a & ${ }^{a}$ & ${ }^{a}$ & a & .500 \\
\hline & USEGPS & a & a & a & a & a & a & a \\
\hline & USEEDI & .866 & a & a & a & .000 & a & a \\
\hline & USEWEB & -.560 & a & .000 & -.079 & -.065 & a & $a$ \\
\hline
\end{tabular}




\begin{tabular}{|c|c|c|c|c|c|c|c|c|}
\hline & & USEERP & USEBAR & USETRACK & USEGIS & USEGPS & USEEDI & USEWEB \\
\hline \multirow{14}{*}{$\begin{array}{l}\text { Pearson } \\
\text { Correlation }\end{array}$} & AVAERP & a & a & .500 & 1.000 ** & a & .866 & -.560 \\
\hline & AVABAR & .302 & . a & -.756 & $.962^{*}$ & a & a & a \\
\hline & AVATRACK & .500 & -.701 & $-1.000^{* *}$ & . a & a & a & .000 \\
\hline & AVAGIS & . a & .091 & $1.000^{* *}$ & a & a & a & -.079 \\
\hline & AVAGPS & . a & .000 & . a & a & a & .000 & -.065 \\
\hline & AVAEDI & .000 & -.686 & a & a & a & . a & a \\
\hline & AVAWEB & $-1.000 * *$ & -.686 & -.866 & .500 & a & a & a \\
\hline & USEERP & 1.000 & .206 & .213 & .041 & .218 & .000 & .162 \\
\hline & USEBAR & .206 & 1.000 & -.069 & .427 & .486 & .448 & .297 \\
\hline & USETRACK & .213 & -.069 & 1.000 & -.379 & $.925^{* *}$ & .539 & .261 \\
\hline & USEGIS & .041 & .427 & -.379 & 1.000 & .088 & .340 & .637 \\
\hline & USEGPS & .218 & .486 & $.925^{\star *}$ & .088 & 1.000 & $.899^{* *}$ & $.971^{* *}$ \\
\hline & USEEDI & .000 & .448 & .539 & .340 & .899 ** & 1.000 & .102 \\
\hline & USEWEB & 162 & 297 & 261 & 637 & $971 * *$ & 102 & 10 \\
\hline
\end{tabular}

$\left({ }^{* *}\right)$ Correlation is significant at the 0.01 level (2-tailed) and $\left(^{*}\right)$ at the 0.05 level (2-tailed)

(a) Cannot be computed because at least on e of the variables is constant.

\section{Table 11. Correlation among availability and use of technology}

From both tables, integrated systems are perceived as in tight relation with bar coding, EDI and satellite positioning, but only linked to geographical databases. It could be a bias caused by the selling strategies of such equipment providers.

Tracking is associated with geographical databases, in contrast with the opposite relationship assigned to shared applications with suppliers and customers. This points out power conflicts derived from information control. In Venezuela, it is common to relate power to information access.

It is important to mention the quite perfectly opposite relationship between tracking availability and usage, as a different behavior than the observed with geographical databases where the relation is direct.

The use of Internet is perceived as associated to all the recent tendencies (tracking, GIS, GPS, EDI, etc.) with opposite relation to the use of integrated systems. It looks like Internet is viewed as the way to avoid direct integration efforts.

Satellite technology is linked to EDI, Internet and tracking. This coincides with the systems operated by some foreign package carriers.

A total of eight explanatory variables for the adoption of IT were considered: precision, information comprehension, speed, accessibility along the supply chain, facilities to develop internal communications, professional appearance, transparency, and attraction and retention effect (in this order of appearance in the correlation table). The main reasons argued by the firms to use information technology are speed and precision, correlated, as is speed and internal communications (results of the study of correlation are showed in Table 12).

Correlations

\begin{tabular}{|c|c|c|c|c|c|c|c|c|c|}
\hline & & PRECIS & COMPREH & SPEED & ACCESS & INTCOMM & APPEAR & TRANSPAR & RETENT \\
\hline \multirow{8}{*}{$\begin{array}{l}\text { Pearson } \\
\text { Correlation }\end{array}$} & PRECIS & 1.000 & .318 & $.432 *$ & .073 & .225 & .282 & -.035 & -.300 \\
\hline & COMPREH & .318 & 1.000 & .360 & .106 & $.426^{*}$ & .228 & -.012 & -.065 \\
\hline & SPEED & $.432 *$ & .360 & 1.000 & -.054 & $.402 *$ & -.069 & .291 & .020 \\
\hline & ACCESS & .073 & .106 & -.054 & 1.000 & .313 & .375 & .357 & $.442 *$ \\
\hline & INTCOMM & .225 & $.426^{*}$ & $.402^{*}$ & .313 & 1.000 & .105 & .285 & .316 \\
\hline & APPEAR & .282 & .228 & -.069 & .375 & .105 & 1.000 & .277 & .236 \\
\hline & TRANSPAR & -.035 & -.012 & .291 & .357 & .285 & .277 & 1.000 & $.495^{*}$ \\
\hline & RETENT & -.300 & -.065 & .020 & $.442^{*}$ & .316 & .236 & $.495^{*}$ & 1.000 \\
\hline
\end{tabular}

(*) Correlation is significant at the 0.05 level (2-tailed).

Table 12. Relations among reasons for using IT in logistics 
Transparency and accessibility are related to the market (attraction and retention effect), while the comprehension of information is linked to internal communications. This points out to providing information to internal clients but only data to external ones.

Future tendencies in IT use

When asked to identify which technologies are more likely to impact logistics, respondents ranked first product tracking, advanced planning capabilities (APS-type) and automated/intelligent infrastructure. This indicates links between flexible/dynamic resource planning and flexibility to respond to product innovations, indicating a tendency to improve the information available to the client.

\section{Reported Performance In Logistic Activities}

Although logistic performance is comparable to the reported by the Council of Logistics Management (CLM), in terms of lead-time, order filling and precision, there are important gaps between the customer's needs and suppliers' performance.

Anyway, in all the reported cases, the performance required (and obtained) by the customer is better than that required and obtained by the suppliers.

This shows an important opportunity for a third party to manage the whole supply chain.

Average performance is shown in Table 17.
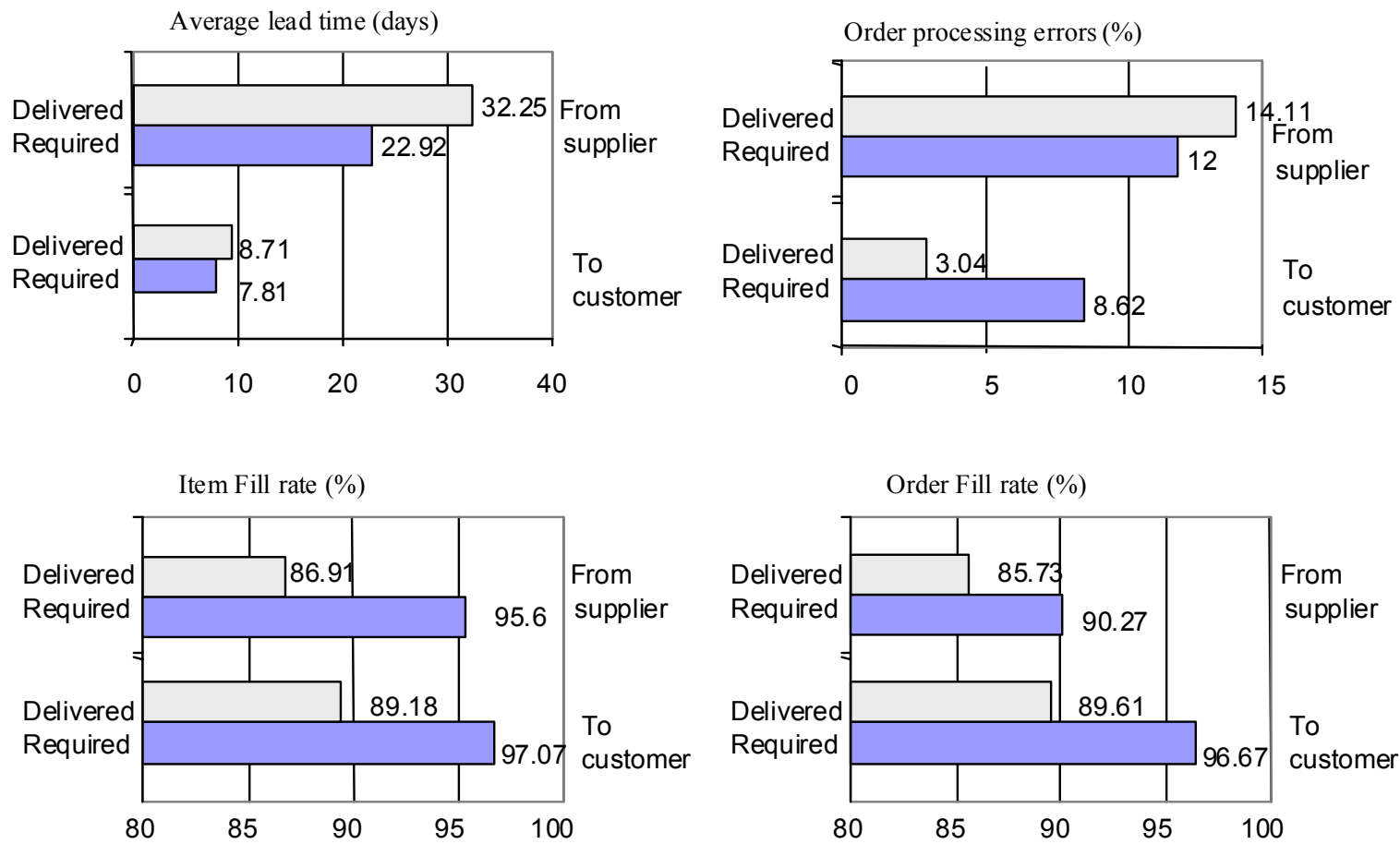

Table 17. Reported performance for performance in logistic activities 


\section{Concluding Remarks}

Logistic practices adopted in Venezuela follow conservative strategies. The market characteristics small size, lack of service providers- conspire against the development of outsourcing practices. This, in one hand, and the negative perception of outsourcing, on the other, creates opportunities for third party logistics activities focused on delivering appropriate services with cost efficiency in strategic alliances. As predicted by the analysis these activities have slowly developed in Venezuela since the survey took place.

Information technology tools have been slow to adapt by leading companies that disregard recent trends and favor the use of mature technologies has been chosen as the safest strategy, even when there are important gaps between the customers' needs and the services delivered by the suppliers.

The transactional focus of the relevant actors limits the long-term vision of the business, favoring vertical integration and excluding any possible loss of power that could result from the use of best practices in logistics.

Integration of the supply chain is the key pending issue in order to develop the logistic potential of Venezuela. Although some qualifiers are present (geographic positioning and human resources availability), the lack of infrastructure and technology slows down the implementation of logistic practices focused on improving the services delivered by means of cost reduction and quality improvement. 


\section{Appendix 1}

The following table (A.1) presents the definitions of the reported variables, alphabetically ordered.

\begin{tabular}{|c|c|}
\hline NAME & DEFINITION \\
\hline 3PCHANN & $\begin{array}{l}\text { Degree of importance assigned to the outsourcing of distribution channels as a } \\
\text { success factor }\end{array}$ \\
\hline ACCESS & $\begin{array}{l}\text { Reason perceived to use information technology: Information accessible by } \\
\text { consumers and suppliers }\end{array}$ \\
\hline AFTSALES & $\begin{array}{l}\text { Degree of importance assigned to after sales service as a success factor in developing } \\
\text { logistics }\end{array}$ \\
\hline APPEAR & Reason perceived to use information technology in the firm: Professional appearance \\
\hline AVABAR & Degree of technology availability in the firm: Bar Coding \\
\hline AVAEDI & Degree of technology availability in the firm: Electronic Data Interchange(EDI) \\
\hline AVAERP & Degree of technology availability in the firm: Integrated systems (ERP) \\
\hline AVAGIS & Degree of technology availability in the firm: Geographic Databases (GIS) \\
\hline AVAGPS & Degree of technology availability in the firm: Satellite Positioning Systems (GPS) \\
\hline $\begin{array}{l}\text { AVATRAC } \\
\text { K }\end{array}$ & Degree of technology availability in the firm: Electronic Tracking \\
\hline AVAWEB & Degree of technology availability in the firm: E-Commerce via WEB \\
\hline CLIENTS & $\begin{array}{l}\text { Importance of long-term relationship with clients as a key factor in logistics } \\
\text { development }\end{array}$ \\
\hline $\begin{array}{l}\text { COMPETI } \\
\mathrm{T}\end{array}$ & $\begin{array}{l}\text { Perceived importance of foreigner competition impact as a threat to logistics } \\
\text { development }\end{array}$ \\
\hline COMPREH & $\begin{array}{l}\text { Reason perceived to use information technology in the firm: Information's degree of } \\
\text { comprehension }\end{array}$ \\
\hline COSTS & $\begin{array}{l}\text { Importance perceived of low transportation costs to measure success in developing } \\
\text { logistics }\end{array}$ \\
\hline DELIVER & $\begin{array}{l}\text { Degree of importance assigned to lead-time as a success factor in developing } \\
\text { logistics }\end{array}$ \\
\hline ENVIRON & $\begin{array}{l}\text { Uncertainty about economic environment as a threat to logistic activities' } \\
\text { development }\end{array}$ \\
\hline FIFTHCRI & Fifth criterion to select providers and be selected as provider: geographic location \\
\hline FIRSTCRI & Most important criterion to select providers and be selected as provider: quality \\
\hline FOURTCRI & Fourth criterion to select providers and be selected as provider: response flexibility \\
\hline IMPADM & $\begin{array}{l}\text { Degree of importance assigned to the outsourcing of logistic-related administrative } \\
\text { tasks }\end{array}$ \\
\hline $\begin{array}{l}\text { IMPBENC } \\
\mathrm{H}\end{array}$ & Degree of importance assigned to benchmarking as a successful logistics practice \\
\hline IMPCLIEN & Degree of importance assigned to integration with clients as a good practice \\
\hline IMPCROSS & Degree of importance assigned to Cross-Docking \\
\hline IMPDISTR & Degree of importance assigned to the outsourcing of distribution activity \\
\hline IMPECR & $\begin{array}{l}\text { Degree of importance perceived of Efficient Consumer Response (ECR) as a } \\
\text { successful practice }\end{array}$ \\
\hline IMPINFSY & Degree of importance assigned to the outsourcing of information systems \\
\hline NAME & DEFINITION \\
\hline IMPINLOG & Degree of importance assigned to the outsourcing of internal logistics activities \\
\hline IMPOUTS & Importance assigned to outsourcing as a successful logistics practice \\
\hline
\end{tabular}




\begin{tabular}{|c|c|}
\hline $\mathrm{O}$ & \\
\hline IMPPERFO & $\begin{array}{l}\text { Importance assigned to formal performance evaluation as a good business practice in } \\
\text { logistics }\end{array}$ \\
\hline IMPSUPPL & Degree of importance assigned to integration with suppliers as a successful practice \\
\hline $\begin{array}{l}\text { IMPTRAN } \\
\text { S }\end{array}$ & Degree of importance assigned to transportation activity in the firm \\
\hline $\begin{array}{l}\text { IMPWARE } \\
\text { H }\end{array}$ & Degree of importance assigned to the outsourcing of warehousing activity \\
\hline INFRAST & $\begin{array}{l}\text { Importance assigned to the lack of adequate transport infrastructure as a threat to } \\
\text { logistics }\end{array}$ \\
\hline INTCOMM & Reason perceived to use information technology in the firm: Internal communication \\
\hline \begin{tabular}{l|l} 
NEEDS1 & \\
\end{tabular} & Leading practice used to identify clients' logistics requirements: market research \\
\hline NEEDS2 & Second practice to identify clients' logistics requirements: surveys to clients \\
\hline NEEDS3 & $\begin{array}{l}\text { Third practice to identify clients' logistics requirements: analysis of services } \\
\text { provided by competitors }\end{array}$ \\
\hline NEEDS4 & Fourth practice to identify clients' logistics requirements: focus groups with clients \\
\hline NET & $\begin{array}{l}\text { Importance of a reliable supplier's network to measure success in developing } \\
\text { logistics }\end{array}$ \\
\hline $\begin{array}{l}\text { NOUTCON } \\
\mathrm{T}\end{array}$ & Reason argued to avoid outsourcing of logistics activities: Loss of control (power) \\
\hline $\begin{array}{l}\text { NOUTCOS } \\
\mathrm{T}\end{array}$ & Reason argued for not outsourcing: Outsourcing is more costly than doing internally \\
\hline $\begin{array}{l}\text { NOUTLEG } \\
\text { A }\end{array}$ & $\begin{array}{l}\text { Reason argued to avoid outsourcing of logistics activities: Legal obligations/labor } \\
\text { relations }\end{array}$ \\
\hline $\begin{array}{l}\text { NOUTPRO } \\
\text { T }\end{array}$ & $\begin{array}{l}\text { Reason argued to avoid outsourcing of logistics activities: Protection of } \\
\text { reliability/intellectual property }\end{array}$ \\
\hline $\begin{array}{l}\text { NOUTUNA } \\
\mathrm{V}\end{array}$ & Reason argued to avoid outsourcing: Service/Capacity is unavailable in the market \\
\hline $\begin{array}{l}\text { OWNCHA } \\
\text { NN }\end{array}$ & $\begin{array}{l}\text { Degree of importance assigned to directly-owning distribution channels as a success } \\
\text { factor }\end{array}$ \\
\hline PERSON & Lack of qualified personnel as a threat to logistic activities' development \\
\hline PRECIS & $\begin{array}{l}\text { Reason perceived to use information technology in the firm: Information's degree of } \\
\text { precision }\end{array}$ \\
\hline REACORE & Reason argued to outsource logistics activities: Focus on core activities \\
\hline REACOST & Reason argued to outsource logistics activities: Cost-Reduction \\
\hline REAQUAL & Reason argued to outsource logistics activities: Improvement of service quality \\
\hline $\begin{array}{l}\text { REARESO } \\
\text { U }\end{array}$ & Reason argued to outsource logistics activities: Better resource's usage \\
\hline RETENT & $\begin{array}{l}\text { Reason perceived to use information technology in the firm: Attract and retain } \\
\text { clients }\end{array}$ \\
\hline SECONCRI & Second criterion to select providers and be selected as provider: delivery reliability \\
\hline SERVICE & $\begin{array}{l}\text { Perceived impact from lack of efficient custom services as a threat to logistics } \\
\text { development }\end{array}$ \\
\hline SPEED & Reason perceived to use information technology in the firm: Speed \\
\hline THIRDCRI & Third criterion to select providers and be selected as provider: price \\
\hline $\begin{array}{l}\text { TRANSPA } \\
\text { R }\end{array}$ & $\begin{array}{l}\text { Reason perceived to use information technology in the firm: Transparency to clients } \\
\text { and suppliers }\end{array}$ \\
\hline & Importance assigned to absence of knowledge about exportation markets as a \\
\hline
\end{tabular}




\begin{tabular}{|l|l|}
\hline N & logistics threat \\
\hline USEADM & Utilization of outsourcing in billing and collect \\
\hline USEAPLIC & Degree of usage in your firm: Shared-applications with suppliers and clients \\
\hline USEBAR & Degree of usage in your firm: Bar coding \\
\hline $\begin{array}{l}\text { USEBENC } \\
\text { H }\end{array}$ & Practice's degree of usage: Benchmarking \\
\hline USECLIEN & Practice's degree of usage: integration with clients \\
\hline $\begin{array}{l}\text { USECROS } \\
\text { S }\end{array}$ & Practice's degree of usage: Cross-Docking (CD) \\
\hline USEDISTR & Utilization of outsourcing in external distribution \\
\hline USEECR & Practice's degree of usage: Efficient Consumer Response (ECR) \\
\hline USEEDI & Degree of usage in your firm: Electronic Data Interchange(EDI) \\
\hline USEERP & Degree of usage in your firm: Integrated systems (ERP) \\
\hline $\begin{array}{l}\text { USEEVAL } \\
\text { U }\end{array}$ & Practice's degree of usage: Formal performance evaluation \\
\hline USEGIS & Degree of usage in your firm: Geographic databases (GIS) \\
\hline USEGPS & Degree of usage in your firm: Satellite Positioning Systems (GPS) \\
\hline USEINFSY & Utilization of outsourcing in information systems support \\
\hline $\begin{array}{l}\text { USEINLO } \\
\text { G }\end{array}$ & Utilization of outsourcing in internal distribution \\
\hline $\begin{array}{l}\text { USEOUTS } \\
\text { O }\end{array}$ & Practice's degree of usage: Outsourcing \\
\hline USESUPPL & Practice's degree of usage: integration with suppliers \\
\hline $\begin{array}{l}\text { USETRAC } \\
\text { K }\end{array}$ & Degree of usage in your firm: Electronic tracking \\
\hline $\begin{array}{l}\text { USETRAN } \\
\text { S }\end{array}$ & Utilization of outsourcing in transportation \\
\hline $\begin{array}{l}\text { USEWARE } \\
\text { H }\end{array}$ & Utilization of outsourcing in warehousing \\
\hline USEWEB & Degree of usage in your firm: E-commerce via WEB \\
\hline
\end{tabular}

Table A.1 Definitions of the reported variables 


\section{Appendix 2. Variance analysis}

Total Variance Explained

\begin{tabular}{|c|c|c|c|c|c|c|c|c|c|}
\hline \multirow[b]{2}{*}{ Component } & \multicolumn{3}{|c|}{ Initial Eigenvalues } & \multicolumn{3}{|c|}{ Extraction Sums of Squared Loadings } & \multicolumn{3}{|c|}{ Rotation Sums of Squared Loadings } \\
\hline & Total & $\begin{array}{c}\% \text { of } \\
\text { Variance }\end{array}$ & $\begin{array}{c}\text { Cumulative } \\
\%\end{array}$ & Total & $\begin{array}{c}\% \text { of } \\
\text { Variance }\end{array}$ & $\begin{array}{c}\text { Cumulative } \\
\%\end{array}$ & Total & $\begin{array}{c}\% \text { of } \\
\text { Variance }\end{array}$ & $\begin{array}{c}\text { Cumulative } \\
\%\end{array}$ \\
\hline 1 & 2.103 & 30.044 & 30.044 & 2.103 & 30.044 & 30.044 & 2.086 & 29.803 & 29.803 \\
\hline 2 & 1.782 & 25.459 & 55.503 & 1.782 & 25.459 & 55.503 & 1.542 & 22.022 & 51.825 \\
\hline 3 & 1.122 & 16.029 & 71.532 & 1.122 & 16.029 & 71.532 & 1.380 & 19.707 & 71.532 \\
\hline 4 & .949 & 13.560 & 85.092 & & & & & & \\
\hline 5 & .570 & 8.143 & 93.235 & & & & & & \\
\hline 6 & .268 & 3.833 & 97.067 & & & & & & \\
\hline 7 & .205 & 2.933 & 100.000 & & & & & & \\
\hline
\end{tabular}

Extraction Method: Principal Component Analysis.

Table a1. Total explained variance for key elements in the logistic strategy

\begin{tabular}{|c|c|c|c|c|c|c|c|c|c|}
\hline \multirow[b]{2}{*}{ Component } & \multicolumn{3}{|c|}{ Initial Eigenvalues } & \multicolumn{3}{|c|}{ Extraction Sums of Squared Loadings } & \multicolumn{3}{|c|}{ Rotation Sums of Squared Loadings } \\
\hline & Total & $\begin{array}{c}\% \text { of } \\
\text { Variance }\end{array}$ & $\begin{array}{c}\text { Cumulative } \\
\%\end{array}$ & Total & $\begin{array}{c}\% \text { of } \\
\text { Variance }\end{array}$ & $\begin{array}{c}\text { Cumulative } \\
\%\end{array}$ & Total & $\begin{array}{c}\% \text { of } \\
\text { Variance }\end{array}$ & $\begin{array}{c}\text { Cumulative } \\
\%\end{array}$ \\
\hline 1 & 2.121 & 35.358 & 35.358 & 2.121 & 35.358 & 35.358 & 1.954 & 32.575 & 32.575 \\
\hline 2 & 1.290 & 21.505 & 56.863 & 1.290 & 21.505 & 56.863 & 1.457 & 24.288 & 56.863 \\
\hline 3 & .917 & 15.277 & 72.140 & & & & & & \\
\hline 4 & .799 & 13.312 & 85.453 & & & & & & \\
\hline 5 & .690 & 11.505 & 96.958 & & & & & & \\
\hline 6 & .183 & 3.042 & 100.000 & & & & & & \\
\hline
\end{tabular}

Extraction Method: Principal Component Analysis.

Table a2. Total explained variance for threats to logistics development

Total Variance Explained

\begin{tabular}{|c|c|c|c|c|c|c|c|c|c|}
\hline \multirow[b]{2}{*}{ Component } & \multicolumn{3}{|c|}{ Initial Eigenvalues } & \multicolumn{3}{|c|}{ Extraction Sums of Squared Loadings } & \multicolumn{3}{|c|}{ Rotation Sums of Squared Loadings } \\
\hline & Total & $\begin{array}{c}\% \text { of } \\
\text { Variance }\end{array}$ & $\begin{array}{c}\text { Cumulative } \\
\%\end{array}$ & Total & $\begin{array}{c}\% \text { of } \\
\text { Variance }\end{array}$ & $\begin{array}{c}\text { Cumulative } \\
\%\end{array}$ & Total & $\begin{array}{c}\% \text { of } \\
\text { Variance }\end{array}$ & $\begin{array}{c}\text { Cumulative } \\
\%\end{array}$ \\
\hline 1 & 4.256 & 30.396 & 30.396 & 4.256 & 30.396 & 30.396 & 2.822 & 20.156 & 20.156 \\
\hline 2 & 3.257 & 23.266 & 53.663 & 3.257 & 23.266 & 53.663 & 2.645 & 18.892 & 39.048 \\
\hline 3 & 2.096 & 14.971 & 68.634 & 2.096 & 14.971 & 68.634 & 2.640 & 18.857 & 57.905 \\
\hline 4 & 1.762 & 12.584 & 81.218 & 1.762 & 12.584 & 81.218 & 2.503 & 17.878 & 75.784 \\
\hline 5 & 1.265 & 9.032 & 90.250 & 1.265 & 9.032 & 90.250 & 2.025 & 14.467 & 90.250 \\
\hline 6 & .996 & 7.112 & 97.362 & & & & & & \\
\hline 7 & .369 & 2.638 & 100.000 & & & & & & \\
\hline 8 & $2.856 \mathrm{E}-16$ & $2.040 \mathrm{E}-15$ & 100.000 & & & & & & \\
\hline 9 & 2.203E-16 & $1.574 \mathrm{E}-15$ & 100.000 & & & & & & \\
\hline 10 & $1.668 \mathrm{E}-16$ & $1.191 \mathrm{E}-15$ & 100.000 & & & & & & \\
\hline 11 & $-6.46 \mathrm{E}-17$ & $-4.61 \mathrm{E}-16$ & 100.000 & & & & & & \\
\hline 12 & $-1.05 E-16$ & $-7.51 \mathrm{E}-16$ & 100.000 & & & & & & \\
\hline 13 & $-2.57 \mathrm{E}-16$ & $-1.84 \mathrm{E}-15$ & 100.000 & & & & & & \\
\hline 14 & $-5.08 \mathrm{E}-16$ & $-3.63 \mathrm{E}-15$ & 100.000 & & & & & & \\
\hline
\end{tabular}

Extraction Method: Principal Component Analysis.

Table a3. Total explained variance for logistic practices and techniques 


\section{References}

Acosta, R. and Cabanas, L. 1996. Logística comercial en el eje Manaos-Ciudad Guayana: ¿Cómo ser competitivos a las puertas del Mercado Común del Sur. Master thesis IESA, 1996.

Anonymous. 2001. Mexican company offers new Asia-Europe route. Logistics Management and Distribution Report, Feb.

Bowersox, D., Closs, D. and Stank, T. 2000. Ten Mega-Trends that will revolutionize supply chain logistics. Journal of Business Logistics, v21 N2.

Bowman, R. 1998. The Latin American trades. World Trade; Irvine; Mar.

Díaz, A. and C. Pérez. 2000. Logistic Practices in Venezuela: An Exploratory Study. BALAS Proceedings.

Díaz, A., C. Pérez, and B. Sánchez. 1998. Características Logísticas de Venezuela. IESA working paper.

Díaz, A. and Dresner, M. 1997. The Modernization of Ports in Latin America: A Case Study of Puerto

Cabello. IESA Working paper.

Esqueda, P., A. Díaz and B. Sánchez. 1996. The suppliers effect on the petroleum industry in Venezuela. IESA working paper.

Gooley, T. 1998. Site selection in Latin America: Things are looking up. Logistics Management and Distribution Report. Institute for Management Development -IMD- (2000). The World Competitiveness Yearbook. Switzerland.

Wilner, F. 2000. Ocean-to-ocean by rail. Traffic World, March.

Zinn, W. 1996. The New Logistics in Latin America: An Overview of Current Status and Opportunities. The International Journal of Logistics Management 7. 